\title{
Inhibitors of tumor necrosis factor-a and mechanisms of their action
}

\author{
Biljana Bufan*, Ivan Jančić, Zorica Stojić-Vukanić \\ University of Belgrade - Faculty of Pharmacy, Department of Microbiology and \\ Immunology, Vojvode Stepe 450, 11000 Belgrade, Serbia
}

*Corresponding author, e-mail: bbiljana@ pharmacy.bg.ac.rs

\begin{abstract}
Tumor necrosis factor (TNF)- $\alpha$ is a proinflammatory cytokine with a role in immunity to pathogens, as well as in the pathogenesis of several autoimmune/inflammatory diseases. Biological drugs targeting this cytokine and inhibiting its effects are designed. Until today, five TNF- $\alpha$ inhibitors are approved: infliximab, adalimumab, golimumab (monoclonal antibodies), certolizumab pegol (pegylated antigen-binding fragment of immunoglobulin), and etanercept [TNF receptor type 2-fragment crystallizable $(\mathrm{Fc})$ of immunoglobulin fusion protein]. Their approved biosimilars are on the market, too. They are mainly used for the treatment of rheumatoid arthritis, inflammatory bowel disease, and psoriasis. Although TNF- $\alpha$ inhibitors are present in clinical practice for more than two decades and are established as an efficacious therapeutics, researchers are still occupied by revealing the complex mechanisms of their action. Namely, in addition to binding and neutralisation of soluble TNF- $\alpha$, these drugs also bind/block transmembrane form of TNF- $\alpha$ (tmTNF- $\alpha$ ), trigger diverse intracellular signals in tmTNF- $\alpha$ positive cells (a process named "reverse signalling") or, if they have an Fc fragment, mediate killing of tmTNF- $\alpha$-expressing cells by other immune cells or the complement system. Also, TNF- $\alpha$ inhibitors that contain Fc portion of the $\mathrm{IgG}$ antibody may affect Fc receptor-expressing cells and have an effector function quite independent of their TNF- $\alpha$ neutralisation capacity.
\end{abstract}

Key words: TNF- $\alpha$ inhibitors; TNF- $\alpha$ neutralisation; TNF receptors;

transmembrane TNF- $\alpha$ 


\section{Introduction}

Tumor necrosis factor (TNF)- $\alpha$ inhibitors are in use for more than two decades in the treatment of autoimmune/inflammatory diseases where overproduction of TNF- $\alpha$, a potent proinflammatory cytokine, has an important role in pathogenesis (1). Currently, five TNF- $\alpha$ inhibitors (infliximab, adalimumab, etanercept, certolizumab pegol and golimumab) are approved by the U.S. Food and Drug Administration and European Medicines Agency (Table I). The first three drugs were initially developed for the therapy of rheumatoid arthritis (RA), but current indications also include inflammatory bowel disease (IBD), psoriasis, psoriatic arthritis, ankylosing spondylitis, juvenile idiopathic arthritis and hidradenitis suppurativa $(1,2)$ (Table II).

Anti-TNF- $\alpha$ agents are primarily developed to target soluble (s)TNF- $\alpha$ and inhibit its action. However, although these drugs were equally successful in the treatment of RA, their efficacy differs when they are used in the therapy of IBD $(3,4)$. These findings pointed out that TNF- $\alpha$ inhibitors act in a way more complex than a simple neutralisation of sTNF- $\alpha$. Thus their effects may also include blocking transmembrane (tm)TNF- $\alpha$ and lymphotoxin (LT), signalling through tmTNF- $\alpha$, and/or effects by fragment crystallizable $(\mathrm{Fc}) \gamma$ receptor $(\mathrm{Fc} \gamma \mathrm{R})$-expressing cells $(3,4)$.

Revealing and understanding the mechanisms of action for biologic agents targeting TNF- $\alpha$, could significantly improve the efficacy of this class of drugs and contribute to the reduction of their side effects.

\section{TNF- $\alpha$}

TNF- $\alpha$ was discovered in 1975 as a molecule whose production was induced by endotoxin and was able to provoke hemorrhagic necrosis of sarcomas transplanted into mice (5). It is known as the cytokine with the most pleiotropic effects of all mammalian cytokines, and its biologic effects are mediated through membrane receptors on different cell types (6). TNF- $\alpha$ is produced in a large amounts during infections with Gramnegative and Gram-positive bacteria and is responsible for systemic complications in severe infections $(6,7)$. Also, the development of some autoimmune/inflammatory diseases, such as RA, IBD, psoriasis, and others, as well as cancers and cardiovascular diseases is linked with uncontrolled production and/or function of this cytokine $(2,8)$. In addition to its role in immunity to pathogens and autoimmune/inflammatory diseases, TNF- $\alpha$ also has a homeostatic function which is mediated by molecular and cellular pathways distinct from pathogenic ones $(2,8)$.

\section{Production and structure of TNF- $\alpha$}

The main TNF- $\alpha$ producers are activated mononuclear phagocytes, activated Tlymphocytes, and natural killer (NK) cells. Mast cells, endothelial cells, fibroblasts, 
osteoclasts, neutrophils, smooth, and cardiac muscle cells can produce this cytokine as well $(7,8)$. Production of this cytokine is induced upon activation of several receptors of innate immunity, either by microbial (e.g. lipopolysaccharide; LPS) or endogenous (cytokines, damaged cells) products (9).

In the cells that produce TNF- $\alpha$, it is firstly synthesized and expressed in a form of a transmembrane protein, also known as pro-TNF- $\alpha(3,6,7)$. Membrane-associated metalloproteinases called TNF- $\alpha$ converting enzyme, cleave the membrane form and release a sTNF- $\alpha$ that circulates through the body and can act, contrary to tmTNF- $\alpha$, at sites that are distant from the site of synthesis $(3,6,7)$. Both forms of the cytokine, membrane, and soluble, are homotrimers. Three $17 \mathrm{kDa}$-subunits polymerize and form a triangular pyramidal structure of sTNF- $\alpha$, where each side of the pyramid is formed by one subunit. Receptor-binding sites are at the base of the pyramid, allowing simultaneous binding of the cytokine to three receptor molecules. The tmTNF- $\alpha$ also appears as a homotrimer consisting of uncleaved monomers, $26 \mathrm{kDa}$ each $(3,7,10)$.

\section{TNF receptors}

TNF- $\alpha$ exerts its effect by binding to TNF receptors type 1 (TNFR1) and type 2 (TNFR2), and both forms of cytokine act through both types of TNFR. However, sTNF$\alpha$ has a significant preference for TNFR1, while tmTNF- $\alpha$ is a more potent ligand for TNFR2 $(3,6)$.

These two receptors have different patterns of expression, a different affinity for ligands, and activate various signalling pathway upon ligand binding (1). Also, their expressions are differently regulated in health and disease (1). TNFR1 is constitutively expressed on almost all nucleated cells and has a role in initiating inflammatory reaction and mediating apoptosis (1). Expression of TNFR2 is inducible and is limited to specific cell types (endothelial cells, lymphocytes, cardiac myocytes, oligodendrocytes, microglia, and astrocytes) (11). It appears that it has an important role in homeostasis and tissue repair, and is activated mainly by tmTNF- $\alpha(1,3,12)$.

Interestingly, tmTNF- $\alpha$ transmits signal not only as a ligand but also as a receptor through the cell to cell contact, acting as a bipolar molecule (3). When it acts as a ligand, tmTNF- $\alpha$-bearing cells, in direct contact-dependent fashion, induce signals in target cells that express TNFR1 and/or TNFR2. Also, binding of TNFR to tmTNF- $\alpha$ results in signalling back in tmTNF- $\alpha$-bearing cell, in the process known as "outside-to-inside signalling" or "reverse signalling" $(6,13)$. The biological significance of reverse signalling has not yet been elucidated completely (3).

\section{Roles of TNF- $\alpha$ in health and disease}

The main physiological role of TNF- $\alpha$ is in host defence to bacteria, viruses, and parasites. However, inappropriate and excessive production of this cytokine can be 
harmful (7). As previously mentioned, it acts proinflammatory, and many of the effects can be explained by its local action on vascular endothelium and consequently on interactions between leukocytes and endothelial cells at the site of infection (7). Namely, in response to this cytokine, endothelial cells express different combinations of adhesion molecules, which in combination with the secretion of various chemokines (14), recruit different populations of leukocytes to the site of infection, independently of antigen recognition (7). Additionally, TNF- $\alpha$ induces expression of cyclooxygenase- 2 in endothelial cells and increases the production of vasodilatory prostaglandin I2, causing 'rubor' and 'calor' due to increased local blood flow (15). Increased vascular permeability, mediated by TNF- $\alpha$, contributes to the development of oedema by increasing trans-endothelial passage of fluid and macromolecules into the site of inflammation. Moreover, TNF- $\alpha$-related expression of procoagulant proteins and downregulation of anticoagulant proteins may result in intravascular thrombosis (16). Also, TNF- $\alpha$ could enhance the antigen presenting function of dendritic cells and, as a result, activate $\mathrm{T}$ cells and stimulate adaptive immunity (14). In severe infections, TNF- $\alpha$ is produced in large quantities, enters the bloodstream, and can cause systemic effects (fever, synthesis of acute phase proteins, shock, intravascular thrombosis, hypoglycemia, cachexia) (17).

In addition to its role in defence against pathogens, TNF- $\alpha$ has a number of homeostatic effects, including the proper formation of lymphoid organs and germinal centres, development of granulomas, resolution of inflammation, induction of tissue repair and inhibition of tumorigenesis $(2,12)$.

Uncontrolled production or function of TNF- $\alpha$ has been associated, as previously mentioned, with the development of autoimmune/inflammatory diseases (2). In RA, a chronic autoimmune disease that affects synovial tissues, proinflammatory cytokines such as interleukin (IL)-1, IL-6, and TNF- $\alpha$, are detected in the affected, inflamed joints (18). Numerous in vivo and in vitro studies have demonstrated that TNF- $\alpha$ has a dominant role in RA pathogenesis $(19,20,21,22)$. In RA patients, accumulation of inflammatory cells, synovial hyperplasia and angiogenesis are seen in affected joints (23). In another rheumatic disease, ankylosing spondylitis, TNF- $\alpha$ has been detected in early active lesions in sacroiliac joints, the main sites of inflammation (24), while an elevated level of this cytokine was measured in patients` serum (25). Crohn`s disease (CD) and ulcerative colitis (UC) are chronic inflammatory disorders that belong to the group of IBD and affect every part of the gastrointestinal tract and colonic mucosa, respectively (26). Increased expression of TNF- $\alpha$ in the lamina propria of the intestinal specimens from patients with CD and UC $(27,28)$, as well as the finding that mice who overexpressed TNF- $\alpha$ develop a CD-like IBD (29) speaks in favor of its importance in the pathogenesis of these diseases. Finally, in patients with an inflammatory skin disorder, psoriasis, inflammatory cell 
infiltrate is found in hyperkeratotic lesions, and TNF- $\alpha$, TNFR1, and TNFR2 are found to be overexpressed in dermal blood vessels of involved skin (30).

\section{TNF- $\alpha$ inhibitors}

As abovementioned, among the five approved TNF- $\alpha$ inhibitors, infliximab, adalimumab and golimumab are monoclonal antibodies (mAbs), certolizumab pegol is Fc-free, PEGylated $\mathrm{mAb}$ and etanercept is a fusion protein (Table I).

Additionally, the patents of etanercept, infliximab and adalimumab expired, and thus several anti-TNF- $\alpha$ biosimilars are already on the market, while a number of them are pending for approval or are in the development process (Table I).

Table I TNF- $\alpha$ inhibitors and their biosimilars.

\begin{tabular}{|c|c|c|c|}
\hline TNF- $\alpha$ inhibitor & Original drug & Biosimilar & Type \\
\hline Etanercept & $\begin{array}{c}\text { Enbrel }{ }^{\circledR} \\
\text { (FDA-1998, EMA-2000) }\end{array}$ & $\begin{array}{c}\text { Erelzi® (FDA-2016, EMA-2017) } \\
\text { Benepali }{ }^{\circledR}(\text { EMA-2016) } \\
\text { Eticovo® }(\text { FDA-2019) }\end{array}$ & $\begin{array}{c}\text { TNFR2 ectodomen fused with } \\
\text { Fc IgG1 }\end{array}$ \\
\hline Infliximab & $\begin{array}{c}\text { Remicade }{ }^{\circledR} \\
\text { (FDA-1998, EMA 1999) }\end{array}$ & $\begin{array}{c}\text { Inflectra } ₫(\text { FDA-2016, EMA-2016), } \\
\text { Remsima® (FDA-2016, EMA-2013) } \\
\text { Infixi® (FDA-2017, EMA-2017), } \\
\text { Flixabi® (EMA-2016), } \\
\text { Renflexis }(\text { FDA-2017), } \\
\text { Zessly® (EMA-2018) } \\
\end{array}$ & Chimeric mouse/human IgG1 \\
\hline Adalimumab & $\begin{array}{c}\text { Humira }{ }^{\circledR} \\
\text { (FDA-2005, EMA-2003) }\end{array}$ & 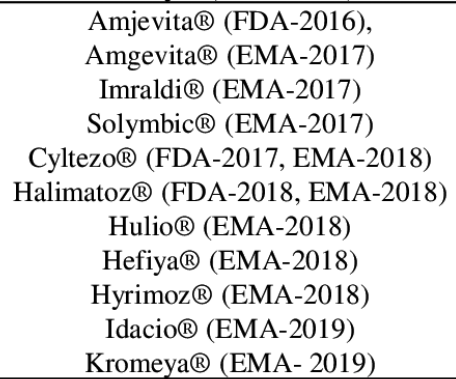 & Human IgG1 \\
\hline $\begin{array}{c}\text { Certolizumab } \\
\text { pegol }\end{array}$ & $\begin{array}{c}\text { Cimzia }{ }^{\circledR} \\
\text { (FDA-2008, EMA-2009) }\end{array}$ & & Humanized, pegylated Fab' \\
\hline Golimumab & $\begin{array}{c}\text { Simponi }{ }^{\circledR} \\
\text { (FDA-2009, EMA-2009) }\end{array}$ & & Human IgG1 \\
\hline
\end{tabular}

The number in parentheses indicates the year of approval; FDA-Food and Drug Administration; EMA-European Medicines Agency

Izvori: http://www.gabionline.net/Biosimilars/General/Biosimilars-of-adalimumab http://www.gabionline.net/Biosimilars/General/Biosimilars-of-infliximab http://www.gabionline.net/Biosimilars/General/Biosimilars-of-etanercept[cited 30.12.2019.]

TNF- $\alpha$ inhibitors are used to treat RA, CD, UC, psoriatic arthritis, polyarticular juvenile idiopathic arthritis, ankylosing spondylitis, hidradenitis suppurativa and uveitis (Table II). Also, these drugs are used „off-label“ in the treatment of Behçet’s disease, 
pyoderma gangrenosum, TNFR-associated periodic fever syndrome, adult-onset Still disease, and systemic-onset juvenile idiopathic arthritis $(1,31)$.

Table II Approved indications of TNF- $\alpha$ inhibitors.

\begin{tabular}{|c|c|}
\hline TNF- $\alpha$ inhibitor & Indications \\
\hline Etanercept & $\begin{array}{c}\text { Rheumatoid arthritis, juvenile idiopathic arthritis, psoriatic } \\
\text { arthritis, ankylosing spondylitis, plaque psoriasis, pediatric plaque } \\
\text { psoriasis }\end{array}$ \\
\hline Adalimumab & $\begin{array}{c}\text { Rheumatoid arthritis, polyarticular juvenile idiopathic arthritis, } \\
\text { axial spondiloarthritis, ankylosing spondylitis, psoriatic arthritis, } \\
\text { psoriasis, Crohn`s disease, pediatric Crohn`s disease, ulcerative } \\
\text { colitis, hydradenitis suppurativa, uveitis }\end{array}$ \\
\hline Infliximab & $\begin{array}{c}\text { Rheumatoid arthritis, adult Crohn's disease, pediatric Crohn's } \\
\text { disease, ulcerative colitis, pediatric ulcerative colitis, ankylosing } \\
\text { spondylitis, psoriatic arthritis, psoriasis }\end{array}$ \\
\hline Certolizumab \\
pegol
\end{tabular}$\quad$\begin{tabular}{c} 
Rheumatoid arthritis \\
\hline Golimumab
\end{tabular}

Modified from Lis et al.(1)

Etanercept $\left(\right.$ Enbrel $\left.^{\circledR}\right)$ is the first TNF- $\alpha$ inhibitor approved for the treatment of RA, and the first recombinant receptor: immunoglobulin (Ig) fusion protein approved for therapeutic use in humans. It contains two extracellular portions of the human TNFR2 and Fc region of human Ig-G1. This Fc region has a hinge, heavy chain constant domains (CH) 2 and 3, but does not have a CH1 domain (3) (Table I, Figure 1). For its production, recombinant DNA technology utilizing Chinese hamster ovary (CHO) mammalian cell expression system was used (32). Etanercept, with its dimeric structure, has a greater affinity of binding and greater competitive inhibition of TNF- $\alpha$ compared with monomeric soluble receptors $(32,33)$. Also, possession of the $\mathrm{IgG} \mathrm{Fc}$ region as a fusion element contributes to its longer half-life in serum, in comparison with monomeric soluble receptors (32). Etanercept is the only TNF- $\alpha$ inhibitor that competitively inhibits the binding of both TNF- $\alpha$ and LT- $\alpha$ to TNFR1 and TNFR2 (32).

Infliximab $\left(\right.$ Remicade $\left.^{\circledR}\right)$ is a monoclonal, chimeric anti-TNF- $\alpha$ mAb with specificity for human TNF- $\alpha$. It consists of murine variable regions of Ig heavy and $\mathrm{k}$ light chain (25\% of the molecule) and a human IgG1 constant region (75\% of the molecule). It binds s- and tm-TNF- $\alpha$ (34) (Table I, Figure 1). 
Adalimumab (Humira ${ }^{\circledR}$ ) is the first fully human high-affinity mAb produced by „phage-display“ technology in CHO mammalian cell line. This antibody contains heavyand light- chain variable regions and constant $\mathrm{IgG} 1: \mathrm{k}$ region of human origin. It is highly selective for s- and tm-TNF- $\alpha$ and does not bind to other cytokines (35) (Table I, Figure $1)$.

Golimumab (Simponi ${ }^{\circledR}$ ) is also human $\operatorname{IgG1:k} \mathrm{mAb}$ with high affinity and selectivity to TNF- $\alpha$. Unlike adalimumab, it is produced by a cell line of murine hybridomas with recombinant DNA technology using transgenic mice (36). These mice are engineered to express human IgG transgenes and after immunization with human recombinant TNF- $\alpha$ they synthesize and secrete high-affinity human mAb specific for human TNF- $\alpha$ (36) (Table I, Figure 1).

Certolizumab pegol $\left(\mathrm{Cimzia}^{\circledR}\right)$ consists of monovalent antigen-binding fragment (Fab') of humanized (approximately 95\% human) IgG1 that is specific for TNF- $\alpha$ and two polyethylene glycol (PEG) chains covalently linked to hinge portion of the molecule (Table I, Figure 1). Although it lacks the Fc region, pegylation prolongs its half-life and solubility, and reduces its immunogenicity and susceptibility to protease digestion $(3,9$, $34)$.
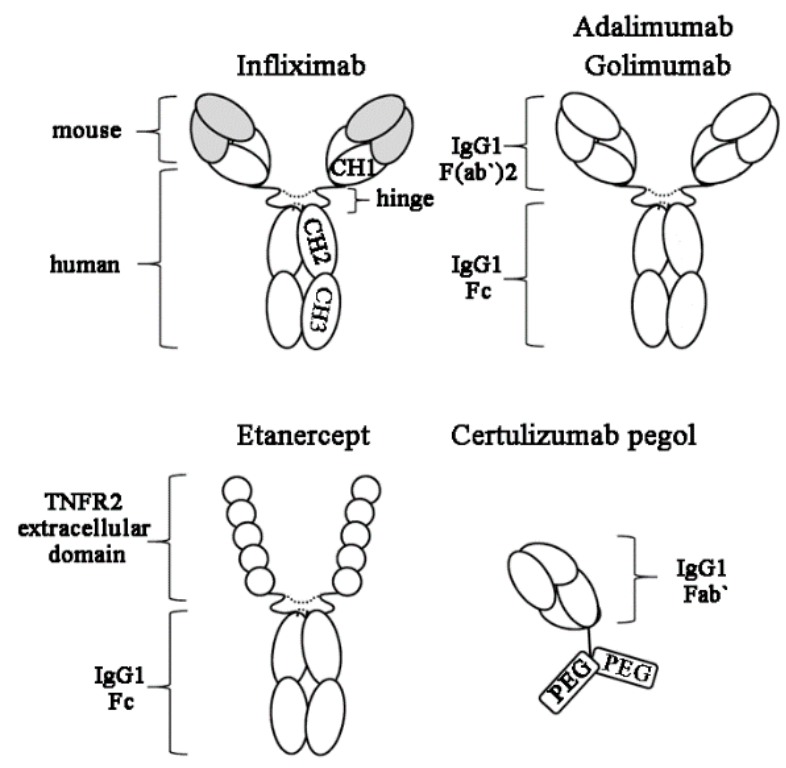

Figure 1. Structure of TNF-a inhibitors. Infliximab is a mouse/human chimeric monoclonal anti-TNF-a IgG1 antibody. Adalimumab and golimumab are human monoclonal anti-TNF- $\alpha$ IgG1 antibodies. Etanercept is a fusion protein consisting of two extracellular domains of human TNFR2 and the Fc region of IgG1. Certolizumab pegol is a pegylated Fab' fragment of humanized monoclonal anti-TNF- $\alpha$ antibody. CH-heavy chain constant domain, PEG- polyethylene glycol, TNFR- receptor for tumor necrosis factor. 
All the abovementioned biological agents have revolutionized RA treatment, whereas their efficacy in the treatment of CD and UC is not equal $(3,4)$. Namely, while full anti-TNF- $\alpha$ mAbs (infliximab, adalimumab, and golimumab) can induce clinical and endoscopic remission in patients with IBD, certolizumab pegol, which lacks the Fc fragment, was less effective than full mAbs, whereas no evidence exists that etanercept can induce clinical remission in $\operatorname{IBD}(3,4)$. It is assumed that structural characteristics/differences between the drugs influence their mechanisms of action and are the cause of the variations in the efficacy in the treatment of IBD (9).

\section{Mechanisms of action}

Although TNF- $\alpha$ inhibitors are more than 20 years in use, the mechanisms of their action have not yet been fully clarified. Primary, they are developed to bind and directly neutralise sTNF- $\alpha$ activity, i.e. to antagonize/block its signalling (9). However, since etanercept, TNF- $\alpha$ inhibitor that targets STNF- $\alpha$, has been successful in RA, but not in IBD treatment $(4,9,37)$, it has been supposed that mechanisms of action of these drugs are much more complex. Today, it is known that other mechanisms contributing to the biological activity of these drugs may include their effects through binding to tmTNF- $\alpha$ and Fc $\gamma \mathrm{R}$-expressing cells $(38,39,40,41,42,43,44,45)$.

\section{Neutralisation of TNF- $\alpha$}

Even though all TNF- $\alpha$ inhibitors have the same target, there are differences in their characteristics of binding, and in the way they neutralise TNF- $\alpha$ (40). Generally, all antiTNF- $\alpha$ agents bind and neutralise sTNF- $\alpha$, but their binding affinity is different $(3,4,38$, 41). Also, it has been reported that the affinity of these agents for tmTNF- $\alpha$ is lower than for its soluble form $(38,41)$. This could be, at least partly, explained by the fact that the effects of these drugs on cells that express tmTNF- $\alpha$ also depend on the concentration of sTNF- $\alpha$ and therefore on the availability of the free TNF- $\alpha$ inhibitor (46). However, data regarding the binding affinity of different TNF- $\alpha$ inhibitors for tmTNF- $\alpha$ are contradictory. Some studies showed no difference in their affinity of binding (38), whereas others found that etanercept does either not bind or binds with low affinity (40, $41,43,44)$. Found discrepancies can be explained by different cell types, methods, and techniques that were used for affinity assessment (4). Since it has been shown that TNFR2, which is a part of etanercept, dissociates swiftly from both sTNF- $\alpha$ and tmTNF$\alpha$, etanercept TNF- $\alpha$ neutralisation capacity is probably short-lived (40). An unstable complex of etanercept/TNF- $\alpha$ contributes to the longer half-life of the drug, but TNF- $\alpha$ released from the complex is biologically active and can bind to its natural receptors (40). Thus, if there is no enough etanercept in tissue to prevent the binding of TNF- $\alpha$ to its natural receptors, incomplete inhibition of proinflammatory action of TNF- $\alpha$ can be expected (40). 
Furthermore, different TNF- $\alpha$ inhibitors have been shown to differ in their ability to cross-link tmTNF- $\alpha$. It has been shown that up to three infliximab molecules can bind to each tmTNF- $\alpha$ homotrimer, resulting in blocking all receptor-binding sites on this cytokine (40). Contrary to this, etanercept binds to tmTNF- $\alpha$ trimer in a one-to-one ratio, blocking two of the three receptor binding sites, so that one receptor binding site stays open/free (40). Thus, it is hypothesized that the flexibility of etanercept, compared with infliximab, is reduced, and thus cross-linking of multiple tmTNF- $\alpha$ molecules is prevented (47). All abovementioned data, together with the fact that infliximab forms more stable complexes with tmTNF- $\alpha$, the neutralisation of which, rather than neutralisation of sTNF- $\alpha$, is crucial in the therapy of IBD, could be a possible explanation why infliximab is effective in the therapy of IBD whereas etanercept did not show any clinical efficacy in patients with $\mathrm{CD}$, and therefore received no approval for IBD treatment (4).

\section{Neutralisation of LTa}

Etanercept, contrary to infliximab and adalimumab, binds and neutralises LT $\alpha 3$, a cytokine that acts through TNFR1 and TNFR2 $(3,38,40)$. Since LT $\alpha 3$ has a role in RA pathogenesis, its neutralisation by etanercept suppresses inflammation and has a favorable effect on this disease (3). The role of LT $\alpha 3$ in the pathogenesis of IBD has not been sufficiently studied. It is supposed that the other form of LT, LT $\alpha 1 \beta 2$, could have a role in the pathogenesis of IBD, but the effects of this cytokine are mediated by LT $\beta$ receptor, and it can not be neutralised by etanercept (3).

\section{Effects on cells that express tmTNF- $\alpha$}

The binding of TNF- $\alpha$ inhibitors to tmTNF- $\alpha$ can induce effects on the tmTNF- $\alpha-$ bearing cells that are, on the one side, the result of reverse signal transduction, and on the other side, may be Fc region-mediated (if the drug has an Fc region), such as cytotoxicity induced by complement and NK cell activation (4).

\section{Reverse signalling}

As abovementioned, tmTNF- $\alpha$ functions not only as a ligand but also as a receptor $(3,4)$. Thus, TNF- $\alpha$ inhibitors in addition to be considered as antagonists, in the case of binding to tmTNF- $\alpha$ can trigger reverse signalling, and might be also viewed as agonists (48).

For the induction of signalling in tmTNF- $\alpha$-expressing cells (reverse signalling), it is necessary that TNF- $\alpha$ inhibitor binds to tmTNF- $\alpha$ with high avidity and form a stable complex, or to cross-link multiple tmTNF- $\alpha$ molecules $(9,49,50)$. As mentioned above, etanercept does not bind to all binding sites of tmTNF- $\alpha$, and it forms less stable complexes compared to infliximab (40), which makes it less efficient in inducing reverse signal transduction. 
Acting as agonists, TNF- $\alpha$ inhibitors suppress the production of inflammatory mediators, induce apoptosis of activated immune cells and block activation and proliferation of immune cells $(3,4,9)$. Namely, several in vitro studies have shown that TNF- $\alpha$ inhibitors (infliximab, adalimumab, and certolizumab pegol), through reverse signalling, suppress the expression of proinflammatory cytokines (TNF, IL-1 $\beta$, and IL-6) in LPS-stimulated human monocytes of healthy individuals and/or patients with CD and RA $(9,50,51,52)$. Etanercept showed a weaker suppressive effect on the production of proinflammatory cytokines by reverse signal transduction $(39,50)$, which may explain its inefficiency in IBD treatment (9).

Mitoma and coworkers (2005) have shown that infliximab causes cell cycle arrest, promotes apoptosis, and stimulates the production of IL-10, an anti-inflammatory cytokine, by reverse signal transduction in an immortalized human T-lymphocyte cells line (Jurkat cells) transfected with tmTNF- $\alpha$ (53). Further, studies have shown that in RA patients TNF- $\alpha$ inhibitors induce IL-10 expression in peripheral blood helper (CD4+) T lymphocytes, including those from patients suffering from RA that are the most pathogenic and produce IL-17 (54). This suggests that modulation of IL-10 expression in effector T cells may represent one of the mechanisms of action for TNF- $\alpha$ inhibitors.

TNF- $\alpha$ inhibitors can induce cell apoptosis by direct activation of caspases or indirectly by blocking NF- $\mathrm{BB}$ activation and transcription of survival signals triggered by tmTNF- $\alpha$ binding to TNFR2 $(4,55,56)$. Several studies have examined the in vivo effects of infliximab in patients with IBD and demonstrated that apoptosis induction in $\mathrm{T}$ lymphocytes and macrophages is important for the clinical efficacy of the drug $(55,57$, 58).

Ten Hove and coworkers (2002) showed an increased number of apoptotic T cells in the colon tissue obtained by biopsy $24 \mathrm{~h}$ after infliximab infusion in patients with refractory $\mathrm{CD}$. Apoptotic T cells were not found among the patients' peripheral blood cells (55). Another study examining the same drug in CD patients showed that the main target cells in the colonic lamina propria that undergo apoptosis are CD4+ T cells (57). Administration of infliximab also increases apoptosis of macrophages in the lamina propria of intestinal mucosa of IBD patients and consequently decreases their number, which was associated with recovery and healing of the mucosa (58). In vitro, infliximab was more potent in inducing apoptosis of CD8+ $\mathrm{T}$ lymphocytes than of CD4+ T lymphocytes isolated from the inflamed skin of patients with psoriasis (59). However, TNF- $\alpha$ inhibitors differ in their ability to induce apoptosis. Nesbitt and coworkers (2007) found that infliximab and adalimumab, contrary to certolizumab pegol, increase the number of apoptotic monocytes and peripheral blood lymphocytes in vitro (52). Also, etanercept shows a weaker proapoptotic effect compared with infliximab and adalimumab, and this might be one of the reasons for its ineffectiveness in the treatment of $\operatorname{IBD}(39,49,52,43)$. Interestingly, clinically effective anti-TNF antibodies can also 
induce mucosal $\mathrm{T}$ cell apoptosis in IBD indirectly, by targeting the tmTNF/TNFR2 pathway. Namely, the development of granulomatous inflammation which is present in CD largely depends on the anti-apoptotic signal induced by ligation of monocytic tmTNF$\alpha$ to TNFR2 expressed by mucosal CD4+ T cells, and inhibition of this interaction by anti-TNF antibodies leads to lamina propria $\mathrm{T}$ cell apoptosis (56).

Furthermore, TNF- $\alpha$ inhibitors with the Fc region can induce apoptosis by antibody-dependent cellular cytotoxicity (ADCC) and complement-dependent cytotoxicity (CDC) reactions (4).

Antibody-dependent cellular cytotoxicity

ADCC is a mechanism of the adaptive immune system in which antibody-tagged target cells are killed via a non-phagocytic mechanism (60). Therefore, upon antibody binding to its target cell, the Fc domain is recognized by the FcR on effector immune cells. The best- known mechanism utilized by ADCC reactions is the release of perforin and granzymes from NK cell granules, with subsequent apoptosis of the target cell (60).

It was found that infliximab, adalimumab, golimumab, and etanercept induce apoptosis of Jurkat T lymphocytes transfected with tmTNF- $\alpha$ in the presence of human peripheral blood mononuclear cells (PBMNC) and NK cells (3). Also, infliximab and adalimumab were more potent than etanercept in the induction of apoptosis of different cells transfected with tmTNF- $\alpha(52,61)$, even though all three TNF- $\alpha$ inhibitors have domains that interact with FcR on effector cells (3). Finally, as expected, certolizumab pegol did not induce an ADCC reaction in vitro (52), since it does not possess an Fc region (4).

\section{Complement-dependent cytotoxicity}

In the CDC, antibodies bound to target cells can activate the complement system, which results in cell death (4). The capability of TNF- $\alpha$ inhibitors to induce CDC was examined and proved in vitro on different cell lines transfected with tmTNF- $\alpha(38,39$, $41,52,61)$. Infliximab, adalimumab, and golimumab have greater potential for CDC induction than etanercept $(38,39,52,61)$, probably due to different structural characteristics $(38,39,52,61)$. Namely, infliximab, adalimumab, and golimumab are full IgG1 mAbs which contain all three $\mathrm{CH}$ domains and successfully activate the complement system (3). Unlike them, etanercept has a $\mathrm{CH} 2$ domain of IgG1 mAb and binds $\mathrm{C} 1$, the first complement component, but does not have a $\mathrm{CH} 1$ domain, which serves as a platform for the binding of $\mathrm{C} 3$ complement component and is required for full activation of the complement system (3). As expected, certolizumab pegol did not show any CDC activity, since it does not have an Fc region (3).

Despite the potential of TNF- $\alpha$ inhibitors to induce CDC of tmTNF- $\alpha$-transfected cell lines in vitro, Kaymakcalan and coworkers (2009) consider that this reaction is not 
an important mechanism of their action in the treatment of inflammatory diseases. Namely, in order to examine this effect in a system that would resemble the conditions of inflammatory diseases as closely as possible, they used in vitro activated normal human PBMNC as targets and showed that infliximab, adalimumab, and etanercept did not induce a CDC reaction (38).

\section{Anti-inflammatory effect of TNF- $\alpha$ inhibitors}

In addition to the aforementioned findings indicating anti-inflammatory effects of anti-TNF- $\alpha$ drugs, additional data proving this effect will be mentioned below. Thus, Butler and coworkers (1995) showed that the presence of anti-TNF- $\alpha$ antibody in rheumatoid synovial membrane cell cultures inhibited the production of proinflammatory cytokines (IL-1 $\beta$, IL-8, IL-6). Shortly thereafter, reduced migration of radiolabeled granulocytes into the synovial membrane of inflamed joints in infliximab-treated RA patients was shown (62). Synovial membrane biopsies of these patients also showed a decreased number of T lymphocytes, B lymphocytes, and macrophages and diminished expression of IL-8 and monocyte chemoattractant protein-1 (MCP-1), regulating monocytes/macrophages migration and infiltration into tissues (62).

The use of TNF blockers in the treatment of CD patients decreases the expression of proinflammatory cytokines (IFN- $\gamma$, TNF- $\alpha$, IL-1 $\beta$ ) and other mediators of inflammation, and suppresses chronic inflammation $(2,63,64)$. This therapy downregulates the expression of CD40 (maturation/activation marker) on intestinal dendritic cells which is expressed at significantly higher levels on cells of this type from CD patients (65). In these patients, the concentration of CD40 ligand in plasma (soluble form) and its expression on peripheral blood $\mathrm{T}$ lymphocytes, as well as expression of CD40 and VCAM-1 adhesion molecules on blood vessel endothelial cells in intestinal mucosa were also diminished after treatment with TNF- $\alpha$ inhibitors (66). Additionally, therapy with TNF- $\alpha$ inhibitors in IBD patients prevents leukocytes from migrating to the site of inflammation by suppressing the expression of chemokines and chemokine receptors (67). It also inhibits intestinal fibroblasts to produce vascular endothelial growth factor, leading to reduced angiogenesis in the intestinal mucosa (68). It is supposed that all abovementioned effects are the results of the blockade of TNFR-mediated signal transduction $(66,68)$ or the induction of reverse signalling $(64,69)$.

\section{Effect on helper and regulatory $T$ lymphocytes}

TNF- $\alpha$ blockade in mice with collagen-induced arthritis (an animal model of RA) ameliorates clinical symptoms of disease (70). The number of pathogenic CD4+ T cells that produce IFN- $\gamma$ and IL-17 was increased in lymph nodes from these animals, but their migration to the inflamed joints was prevented (70). It was previously mentioned that TNF- $\alpha$ inhibitors induce the expression of IL-10 in peripheral blood IL-17-producing CD4+ T cells from RA patients, which are considered less pathogenic (54). 
A study by Nguyen and coworkers (2016) examined the effect of adalimumab and etanercept on regulatory T cells (Treg) in RA patients and healthy controls. They found that monocytes of RA patients exhibit higher levels of tmTNF- $\alpha$ than those of healthy controls (71). Furthermore, binding of adalimumab, but not etanercept, to tmTNF- $\alpha$ on monocytes, increases the expression of this molecule on monocytes in patients with RA, contrary to cells derived from healthy subjects (71). Furthermore, adalimumab had a positive effect, which is a paradox, on the interaction of tmTNF- $\alpha$ on monocytes and TNFR2 on Treg, leading to the expansion of Treg (3). On the other hand, etanercept did not affect Treg expansion in patients with RA (71). Other TNF- $\alpha$ inhibitors (infliximab, golimumab, and certolizumab pegol) were not included/tested in this study $(3,71)$.

Patients with UC and CD, in response to infliximab, adalimumab, and certolizumab pegol therapy, increase the frequency of Treg in peripheral blood $(64,72)$. This increase in Treg correlates with decreased apoptosis, so it is assumed that the prevention of Treg apoptosis is one of the mechanisms of action of TNF- $\alpha$ inhibitors (73). A study by Li and coworkers (2015) showed that IBD patients had a reduced number of Treg in circulation and that the increase in the number of these cells, preceding infliximab therapy correlated with good response to therapy. It has also been shown that a higher basal number of circulating Treg in patients before therapy, positively correlates with the ability to achieve remission after therapy (74). In this regard, it is suggested that Treg number could be a useful predictor of response to anti-TNF therapy and a parameter that could serve to monitor the effectiveness of this therapy (74).

\section{Induction of regulatory (alternatively activated) macrophages}

One of the major mechanisms of action of TNF- $\alpha$ inhibitors is the effect they exert on monocytes/macrophages by binding to $\mathrm{FcR}(44,75)$. The significance of this mechanism, at least in the treatment of IBD, is indicated by the fact that anti-TNF- $\alpha$ IgG4 mAb, marked as CDP571, did not achieve the desired effect in the treatment of CD (44). Namely, this antibody was designed as IgG4 in order to reduce its interaction with FcR, since the IgG4 subclass has a low affinity for binding to FcR (44). However, this change of subclass could be the main cause of its inefficiency in the treatment of CD (44).

Vos and coworkers (2011) showed that in mixed leukocyte reaction mAbs (infliximab or adalimumab), but not etanercept and certolizumab pegol, inhibit $\mathrm{T}$ lymphocyte proliferation. Inhibition of lymphocyte proliferation did not occur in mixed leukocyte reaction when Fc blockers were added, further confirming the significance of the Fc region for the obtained findings (44). It is supposed that bridging of tmTNF- $\alpha$ on lymphocytes with FcR on monocytes/macrophages by anti-TNF- $\alpha$ antibodies induced the differentiation of monocytes into regulatory (mainly IL-10-producing) macrophages that inhibit lymphocyte proliferation (44). In line with these in vitro findings are data that in $\mathrm{CD}$ patients who have responded to infliximab therapy the degree of healing of intestinal 
mucosa correlates with the induction of regulatory macrophages (75). However, these cells were not found in patients who did not respond to infliximab therapy (75). Interestingly, the effect of combined therapy (infliximab plus azathioprine) was more potent in this respect than the effect of infliximab as a monotherapy (75).

Another factor that might be important for the induction of regulatory macrophages is the binding ability of complexes consisting of sTNF- $\alpha /$ tmTNF- $\alpha$ and anti-TNF- $\alpha$ drugs to FcR (3), where larger complexes have a greater binding ability (61). On the contrary, Wojtaland and coworkers (2012) have shown that binding of infliximab/TNF- $\alpha$ complex to FcR on PBMNC from patients with IBD leads to the classical activation of these cells and the production of proinflammatory mediators (MCP-1, IL-6 and IL-8). Adalimumab showed a similar effect, whereas certolizumab pegol, as well as $F\left(a b^{\prime}\right) 2$ fragments of infliximab, did not, suggesting the importance of the Fc portion for this effect (3). Significantly higher expression of mRNA for activating FcR which binds IgG antibodies (FcrRI) in the colon from patients who did not respond to infliximab therapy could, at least partly, explain its failure in CD therapy (45). Having in mind that monocytes/macrophages express different types of $\mathrm{FcR}$, both activating and inhibitory, and that IgG1 can bind to any of them, it is obvious that signal transduction via these receptors is extremely complex (3). Thus, the outcome of ligand/anti-TNF- $\alpha$ antibody complex binding to $\mathrm{Fc} \gamma \mathrm{R}$ (proinflammatory or antiinflammatory response) and clinical response to these drugs could depend on the expression level of each of the receptor types and the presence of their polymorphism(s) (3).

\section{Conclusion}

Biological drugs that inhibit TNF- $\alpha$ have been present in clinical practice for more than two decades for the treatment of various autoimmune and inflammatory diseases where an overproduction of TNF- $\alpha$, a potent proinflammatory cytokine, has an important role in pathogenesis. To date, five TNF- $\alpha$ inhibitors have been approved: infliximab, adalimumab, golimumab (mAbs), certolizumab pegol (PEGylated Fab'), and etanercept (TNFR2: Fc-fusion protein).

All TNF- $\alpha$ inhibitors are effective in the treatment of RA. However, in the treatment of IBD, infliximab, adalimumab, and golimumab have a beneficial effect, while etanercept has no effect.

The mechanisms of action of TNF- $\alpha$ inhibitors are complex. The main mechanism of their action is to neutralise sTNF- $\alpha$ activity and prevent its binding to TNFR1 and TNFR2 and signalling via these receptors. However, it was shown that they exert its clinical effects by binding to tmTNF- $\alpha$, and either block cell to cell contact and/or trigger reverse signalling. Besides, if anti-TNF- $\alpha$ agents have an Fc fragment, they mediate the killing of tmTNF- $\alpha$-expressing cells by other immune cells or the complement system. 
Also, TNF- $\alpha$ inhibitors containing Fc fragment may stimulate FcR-expressing cells and have an effector function quite independent of their TNF- $\alpha$ neutralisation capacity.

Having all the abovementioned in mind it seems that the therapeutic efficacy of inhibitors of TNF- $\alpha$ is a result of multiple mechanisms acting together and revealing these mechanisms will be helpful in the design of future therapeutics and the selection of appropriate drugs for individual patient therapy.

\section{Literature}

1. Lis K, Kuzawińska O, Bałkowiec-Iskra E. Tumor necrosis factor inhibitors - state of knowledge. Arch Med Sci. 2014;10(6):1175-85. doi: 10.5114/aoms.2014.47827

2. Kalliolias GD, Ivashkiv LB. TNF biology, pathogenic mechanisms and emerging therapeutic strategies. Nat Rev Rheumatol. 2016;12(1):49-62. doi: 10.1038/nrrheum.2015.169

3. Mitoma H, Horiuchi T, Tsukamoto H, Ueda N. Molecular mechanisms of action of anti-TNF- $\alpha$ agents-comparison among therapeutic TNF- $\alpha$ antagonists. Cytokine. 2018;101:56-63. doi: 10.1016/j.cyto.2016.08.014

4. Billmeier U, Dieterich W, Neurath MF, Atreya R. Molecular mechanism of action of anti-tumor necrosis factor antibodies in inflammatory bowel diseases. World J Gastroenterol. 2016;22(42): 9300-13. doi: 10.3748/wjg.v22.142.9300

5. Carswell EA, Old LJ, Kassel RL, Green S, Fiore N, Williamson B. An endotoxin induced serum factor that causes necrosis of tumors. Proc Natl Acad Sci USA. 1975;72:3666-70.

6. Sedger LM, McDermott MF. TNF and TNF-receptors: from mediators of cell death and inflammation to therapeutic giants - past, present and future. Cytokine Growth Factor Rev. 2014;25(4):453-72. doi: 10.1016/j.cytogfr.2014.07.016

7. Bradley JR. TNF-mediated inflammatory disease. J Pathol. 2008;214(2):149-60. doi: 10.1002/path.2287

8. Chu WM. Tumor necrosis factor. Cancer Lett. 2013;328(2):222-5. doi: 10.1016/j.canlet.2012.10.014

9. Olesen CM, Coskun M, Peyrin-Biroulet L, Nielsen OH. Mechanisms behind efficacy of tumor necrosis factor inhibitors in inflammatory bowel diseases. Pharmacol Ther. 2016;159:110-9. doi: 10.1016/j.pharmthera.2016.01.001

10. Tang P, Hung M-C, Klostergaard J. Human pro-tumor necrosis factor is a homotrimer. Biochemistry. 1996;35(25):8216-25.

11. Grell M, Wajant H, Zimmermann G, Scheurich P. The type 1 receptor (CD120a) is the high-affinity receptor for soluble tumor necrosis factor. Proc Natl Acad Sci USA. 1998;95(2):570-5.

12. Monaco C, Nanchahal J, Taylor P, Feldmann M. Anti-TNF therapy: past, present and future. Int Immunol. 2015;27(1):55-62. doi: 10.1093/intimm/dxu102 
13. Horiuchi T, Mitoma H, Harashima S, Tsukamoto H, Shimoda T. Transmembrane TNF-alpha: structure, function and interaction with anti-TNF agents. Rheumatology (Oxford). 2010;49(7):121528. doi: 10.1093/rheumatology/keq031

14. Varfolomeev EE, Ashkenazi A. Tumor necrosis factor: an apoptosis JuNKie? Cell. 2004;116(4):4917.

15. Mark KS, Trickler WJ, Miller DW. Tumor necrosis factor-alpha induces cyclooxygenase-2 expression and prostaglandin release in brain microvessel endothelial cells. J Pharmacol Exp Therap. 2001;297(3):1051-8.

16. Bevilacqua MP, Pober JS, Majeau GR, Fiers W, Cotran RS, Gimbrone MA Jr. Recombinant tumor necrosis factor induces procoagulant activity in cultured human vascular endothelium: characterization and comparison with the actions of interleukin 1. Proc Natl Acad Sci USA. 1986;83(12):4533-7.

17. Tracey KJ, Cerami A. Tumor necrosis factor: a pleiotropic cytokine and therapeutic target. Annu Rev Med. 1994.45:491-503. doi:10.1146/annurev.med.45.1.491

18. Feldmann M, Brennan FM, Maini RN. Role of cytokines in rheumatoid arthritis. Annu Rev Immunol. 1996;14:397-440.

19. Brennan FM, Chantry D, Jackson A, Maini R, Feldmann M. Inhibitory effect of TNF $\alpha$ antibodies on synovial cell interleukin-1 production in rheumatoid arthritis. Lancet 1989;2(8657):244-7.

20. Butler DM, Maini RN, Feldmann M, Brennan FM. Modulation of proinflammatory cytokine release in rheumatoid synovial membrane cell cultures. Comparison of monoclonal anti TNF $\alpha$ antibody with the interleukin-1 receptor antagonist. Eur Cytokine Netw 1995;6(4):225-30.

21. Thorbecke GJ, Shah R, Leu CH, Kuruvilla AP, Hardison AM, Palladino MA. Involvement of endogenous tumor necrosis factor alpha and transforming growth factor beta during induction of collagen type II arthritis in mice. Proc Natl Acad Sci USA 1992;89(16):7375-9.

22. Piguet PF, Grau GE, Vesin C, Loetscher H, Gentz R, Lesslauer W. Evolution of collagen arthritis in mice is arrested by treatment with anti-tumour necrosis factor (TNF) antibody or a recombinant soluble TNF receptor. Immunology. 1992;77(4):510-4.

23. Koch AE, Harlow LA, Haines GK, Amento EP, Unemori EN, Wong WL, et al. Vascular endothelial growth factor. A cytokine modulating endothelial function in rheumatoid arthritis. J Immunol. 1994;152(8):4149-56.

24. Francois RJ, Neure L, Sieper J, Braun J. Immunohistological examination of open sacroiliac biopsies of patients with ankylosing spondylitis: detection of tumour necrosis factor alpha in two patients with early disease and transforming growth factor beta in three more advanced cases. Ann Rheumat Dis.2006;65(6):713-20.

25. Lange U, Teichmann J, Stracke H. Correlation between plasma TNF $\alpha$, IGF-1, biochemical markers of bone metabolism, markers of inflammation/disease activity, and clinical manifestations in ankylosing spondylitis. Eur J Med Res. 2000;5(12):507-11.

26. Kaser A, Zeissig S, Blumberg RS. Inflammatory bowel disease. Annu Rev Immunol. 2010;28:573621. doi: 10.1146/annurev-immunol-030409-101225 
27. Breese EJ, Michie CA, Nicholls SW, Murch SH, Williams CB, Domizio P, et al. Tumor necrosis factor alpha-producing cells in the intestinal mucosa of children with inflammatory bowel disease. Gastroenterology.1994;106(6):1455-66.

28. Murch SH, Braegger CP, Walker-Smith JA, MacDonald TT. Location of tumour necrosis factor alpha by immunohistochemistry in chronic inflammatory bowel disease. Gut. 1993;34(12):1705-9.

29. Kontoyiannis D, Pasparakis M, Pizarro TT, Cominelli F, Kollias G. Impaired on/off regulation of TNF biosynthesis in mice lacking TNF AU-rich elements: implications for joint and gutassociated immunopathologies. Immunity. 1999;10(3):387-98.

30. Ettehadi P, Greaves MW, Wallach D, Aderka D, Camp RD. Elevated tumour necrosis factor-alpha $(\mathrm{TNF} \alpha)$ biological activity in psoriatic skin lesions. Clin Exp Immunol.1994;96(1):146-51.

31. Karampetsou MP, Liossis SN, Sfikakis PP. TNF- $\alpha$ antagonists beyond approved indications: stories of success and prospects for the future. QJM. 2010;103:917-28.

32. Haraoui B, Bykerk V. Etanercept in the treatment of rheumatoid arthritis. Ther Clin Risk Manag. 2007;3(1):99-105.

33. Scott LJ. Etanercept: a review of its use in autoimmune inflammatory diseases. Drugs. 2014;74:1379-1410. doi: 10.1007/s40265-014-0258-9

34. Lim H, Lee SH, Lee HT, Lee JU, Son JY, Shin W, Heo YS. Structural biology of the TNF $\alpha$ antagonists used in the treatment of rheumatoid arthritis. Int J Mol Sci. 2018;19(3). pii: E768. doi: 10.3390/ijms 19030768

35. Mease PJ. Adalimumab in the treatment of arthritis. Ther Clin Risk Manag. 2007;3(1):133-48.

36. Rossini M, De Vita S, Ferri C, Govoni M, Paolazzi G, Salvarani C et al. Golimumab: a novel antitumor necrosis factor. Biol Ther. 2013;3:83-107. doi: 10.1007/s13554-013-0012-y

37. Oikonomopoulos A, van Deen WK, Hommes DW. Anti-TNF antibodies in inflammatory bowel disease: do we finally know how it works? Curr Drug Targets. 2013;14:1421-32.

38. Kaymakcalan Z, Sakorafas P, Bose S, Scesney S, Xiong L, Hanzatian DK et al. Comparisons of affinities, avidities, and complement activation of adalimumab, infliximab, and etanercept in binding to soluble and membrane tumor necrosis factor. Clin Immunol. 2009;131(2):308-16. doi: 10.1016/j.clim.2009.01.002

39. Mitoma H, Horiuchi T, Tsukamoto H, Tamimoto Y, Kimoto Y, Uchino A et al. Mechanisms for cytotoxic effects of anti-tumor necrosis factor agents on transmembrane tumor necrosis factor alphaexpressing cells: comparison among infliximab, etanercept, and adalimumab. Arthritis Rheum. 2008;58(5):1248-57.

40. Scallon B, Cai A, Solowski N, Rosenberg A, Song XY, Shealy D et al. Binding and functional comparisons of two types of tumor necrosis factor antagonists. J Pharmacol Exp Ther. 2002;301(2):418-26.

41. Shealy DJ, Cai A, Staquet K, Baker A, Lacy ER, Johns L et al. Characterization of golimumab, a human monoclonal antibody specific for human tumor necrosis factor alpha. mAbs. 2010;2(4):42839. 
42. Ueda N, Tsukamoto H, Mitoma H, Ayano M, Tanaka A, Ohta S et al. The cytotoxic effects of certolizumab pegol and golimumab mediated by transmembrane tumor necrosis factor alpha, Inflamm Bowel Dis. 2013;19(6):1224-31.

43. van den Brande JM, Braat H, van den Brink GR, Versteeg HH, Bauer CA, Hoedemaeker I et al. Infliximab but not etanercept induces apoptosis in lamina propria T-lymphocytes from patients with Crohn's disease. Gastroenterology. 2003;124(7):1774-85.

44. Vos AC, Wildenbergv ME, Duijvestein M, Verhaar AP, van den Brink GR, Hommes DW. Antitumor necrosis factor-alpha antibodies induce regulatory macrophages in an Fc region-dependent manner. Gastroenterology. 2011;140(1):221-30.

45. Wojtal KA,Rogler G,Scharl M,Biedermann L,Frei P,Fried M et al. Fc gamma receptor CD64 modulates the inhibitory activity of infliximab. PLoS One. 2012;7(8):e43361. doi: 10.1371/journal.pone.0043361

46. Slevin SM, Egan LJ. Newinsights into the mechanisms of action of anti-tumor necrosis factor-alpha monoclonal antibodies in inflammatory bowel disease. Inflamm Bowel Dis. 2015;21:2909-20.

47. Kohno T, Tam L-TT, Stevens SR, Louie JS. Binding characteristics of tumor necrosis factor receptor-Fc fusion proteins vs anti-tumor necrosis factor mAbs. J Investig Dermatol Symp Proc. 2007;12:5-8. doi:10.1038/sj.jidsymp.5650034

48. Sipos O, Török A, Kalic T, Duda E, Filkor K. Reverse signaling contributes to control of chronic inflammation by anti-TNF therapeutics. Antibodies. 2015;4:123-40. doi:10.3390/antib4020123

49. Shen C, Assche GV, Colpaert S, Maerten P, Geboes K, Rutgeerts P et al. Adalimumab induces apoptosis of human monocytes: a comparative study with infliximab and etanercept. Aliment Pharmacol Ther. 2005;21:251-8.

50. Kirchner S, Holler E, Haffner S, Andreesen R, Eissner G. Effect of different tumor necrosis factor (TNF) reactive agents on reverse signaling of membrane integrated TNF in monocytes. Cytokine. 2004;28:67-74.

51. Meusch U, Rossol M, Baerwald C, Hauschildt S, Wagner U. Outside-to-inside signaling through transmembrane tumor necrosis factor reverses pathologic interleukin-1beta production and deficient apoptosis of rheumatoid arthritis monocytes. Arthritis Rheum. 2009;60:2612-21.

52. Nesbitt A, Fossati G, Bergin M, Stephens P, Stephens S, Foulkes R et al. Mechanism of action of certolizumab pegol (CDP870): in vitro comparison with other anti-tumor necrosis factor alpha agents, Inflamm Bowel Dis. 2007;13(11):1323-32.

53. Mitoma H, Horiuchi T, Hatta N, Tsukamoto H, Harashima S, Kikuchi Y et al. Infliximab induces potent anti-inflammatory responses by outside-to-inside signals through transmembrane TNF-alpha. Gastroenterology. 2005;128:376-92.

54. Evans HG, Roostalu U, Walter GJ, Gullick NJ, Frederiksen KS, Roberts CA et al. TNF-alpha blockade induces IL-10 expression in human CD4+ T cells. Nat Commun. 2014;5:3199.

55. Ten Hove T, van Montfrans C, Peppelenbosch MP, van Deventer SJ. Infliximab treatment induces apoptosis of lamina propria T lymphocytes in Crohn's disease. Gut. 2002;50(2):206-11. 
56. Atreya R, Zimmer M, Bartsch B, Waldner MJ, Atreya I, Neumann H et al. Antibodies against tumor necrosis factor (TNF) induce T-cell apoptosis in patients with inflammatory bowel diseases via TNF receptor 2 and intestinal CD14(+) macrophages. Gastroenterology. 2011;141:2026-38.

57. van den Brande JM, Koehler TC, Zelinkova Z, Bennink RJ, te Velde AA, ten Cate FJ et al. Prediction of antitumour necrosis factor clinical efficacy by real-time visualisation of apoptosis in patients with Crohn's disease. Gut. 2007;56(4):509-17.

58. Caprioli F, Bose F, Rossi RL, Petti L, Vigano C, Ciafardini C et al. Reduction of CD68+ macrophages and decreased IL-17 expression in intestinal mucosa of patients with inflammatory bowel disease strongly correlate with endoscopic response and mucosal healing following infliximab therapy. Inflamm Bowel Dis. 2013;19(4):729-39.

59. Bedini C, Nasorri F, Girolomoni G, Pita O, Cavani A. Anti tumour necrosis factor-alpha chimeric antibody (infliximab) inhibits activation of skin homing CD4+ and CD8+ T lymphocytes and impairs dendritic cell function. Br J Dermatol. 2007;157(2):249-58.

60. Zahavi D, AlDeghaither D, O’Connell A, Weiner LM. Enhancing antibody-dependent cell-mediated cytotoxicity: a strategy for improving antibody-based immunotherapy. Antibody Therapeutics. 2018;1(1):7-12. https://doi.org/10.1093/abt/tby002

61. Arora T, Padaki R, Liu L, Hamburger AE, Ellison AR, Stevens SR et al. Differences in binding and effector functions between classes of TNF antagonists. Cytokine. 2009;45(2):124-31.

62. Taylor PC, Peters AM, Paleolog E, Chapman PT, Elliott MJ, McCloskey R et al. Reduction of chemokine levels and leukocyte traffic to joints by tumor necrosis factor alpha blockade in patients with rheumatoid arthritis. Arthritis Rheum. 2000;43(1):38-47.

63. Peake ST, Bernardo D, Mann ER, Al-Hassi HO, Knight SC, Hart AL. Mechanisms of action of antitumor necrosis factor alpha agents in Crohn's disease. Inflamm Bowel Dis. 2013;19:1546-55.

64. Olsen T, Cui G, Goll R, Husebekk A, Florholmen J. Infliximab therapy decreases the levels of TNFalpha and IFN-gamma mRNA in colonic mucosa of ulcerative colitis. Scand J Gastroenterol. 2009;44:727-35.

65. Hart AL, Al-Hassi HO, Rigby RJ, Bell SJ, Emmanuel AV, Knight SC et al. Characteristics of intestinal dendritic cells in inflammatory bowel diseases. Gastroenterology. 2005;129:50-65.

66. Danese S, Sans M, Scaldaferri F, Sgambato A, Rutella S, Cittadini A et al. TNF- $\alpha$ blockade downregulates the CD40/CD40L pathway in the mucosal microcirculation: a novel anti-inflammatory mechanism of infliximab in Crohn's disease. J Immunol. 2006;176(4):2617-24. doi.org/10.4049/jimmunol.176.4.2617

67. Arijs I, De Hertogh G, Machiels K, Van Steen K, Lemaire K, Schraenen A et al. Mucosal gene expression of cell adhesion molecules, chemokines, and chemokine receptors in patients with inflammatory bowel disease before and after infliximab treatment. Am J Gastroenterol. 2011;106:748-61. doi: 10.1038/ajg.2011.27

68. Rutella S, Fiorino G, Vetrano S, Correale C, Spinelli A, Pagano N et al. Infliximab therapy inhibits inflammation-induced angiogenesis in the mucosa of patients with Crohn's disease. Am J Gastroenterol. 2011;106(4):762-70. doi: 10.1038/ajg.2011.48

69. Agnholt J, Kaltoft K. Infliximab downregulates interferon-gamma production in activated gut Tlymphocytes from patients with Crohn's disease. Cytokine. 2001;15(4):212-2. 
70. Notley CA, Julia J, Inglis JJ, Alzabin S, McCann FE, McNamee KE et al. Blockade of tumor necrosis factor in collagen-induced arthritis reveals a novel immunoregulatory pathway for Th1 and Th17 cells. J Exp Med. 2008;205(11):2491-7. doi: 10.1084/jem.20072707

71. Nguyen DX, Ehrenstein MR. Anti-TNF drives regulatory $\mathrm{T}$ cell expansion by paradoxically promoting membrane TNF-TNF-RII binding in rheumatoid arthritis. J Exp Med. 2016;213(7):124153.

72. Guidi L, Felice C, Procoli A, Bonanno G, Martinelli E, Marzo M et al. FOXP3(+) T regulatory cell modifications in inflammatory bowel disease patients treated with anti-TNFalpha agents. Biomed Res Int. 2013;2013:286368.

73. Veltkamp C, Anstaett M, Wahl K, Moller S, Gangl S, Bachmann O et al Apoptosis of regulatory T lymphocytes is increased in chronic inflammatory bowel disease and reversed by anti-TNF $\alpha$ treatment. Gut. 2011;60:1345-53.

74. Li Z, Vermeire S, Bullens D, Ferrante M, Van Steen K, Noman M et al. Restoration of Foxp3+ regulatory T-cell subsets and Foxp3- type 1 regulatory-like $\mathrm{T}$ cells in inflammatory bowel diseases during anti-tumor necrosis factor therapy. Inflamm Bowel Dis. 2015;21:2418-28.

75. Vos ACW, Wildenberg ME, Arijs I, Duijvestein M, Verhaar Gert de Hertogh AP, Vermeire S et al. Regulatory macrophages induced by infliximab are involved in healing in vivo and in vitro. Inflamm Bow Dis. 2012;18(3):401-8. doi.org/10.1002/ibd.21818 


\title{
Inhibitori faktora nekroze tumora-a i mehanizmi njihovog dejstva
}

\author{
Biljana Bufan*, Ivan Jančić, Zorica Stojić-Vukanić \\ Univerzitet u Beogradu - Farmaceutski fakultet, Katedra za mikrobiologiju i \\ imunologiju, Vojvode Stepe 450, 11000 Beograd, Srbija \\ *Autor za korespondenciju, e-mail: bbiljana@pharmacy.bg.ac.rs
}

\section{Kratak sadržaj}

Faktor nekroze tumora (TNF)- $\alpha$ je citokin koji ima značajnu ulogu u patogenezi nekih autoimunskih/inflamatornih bolesti. Shodno tome, dizajnirani su biološki lekovi koji ciljano inhibiraju efekte koje on ostvaruje posredstvom svojih receptora. Do danas je odobreno pet lekova koji inhibiraju TNF- $\alpha$ : infliksimab, adalimumab, golimumab (monoklonska antitela), certolizumab pegol (pegilovani antigen-vezujući fragment imunoglobulina) i etanercept [TNF receptor 2-kristalizujući fragment $(\mathrm{Fc})$ imunoglobulina fuzioni protein]. Takođe, brojni biosimilari ovih lekova su odobreni za primenu. Glavne indikacije za primenu anti-TNF- $\alpha$ lekova su: reumatoidni artritis, inflamatorne bolesti creva, psorijaza. Iako se TNF- $\alpha$ inhibitori više od dve decenije uspešno koriste u kliničkoj praksi, složeni mehanizmi njihovog delovanja još uvek nisu potpuno poznati. Naime, pokazano je da se ovi lekovi, osim vezivanja i neutralizacije solubilnog TNF- $\alpha$, mogu vezati i za transmembransku formu ovog citokina i blokirati je i/ili pokrenuti prenos signala u ćeliju koja ispoljava ovaj molekul (,reverzni prenos signala“). Takođe, ovi lekovi, ukoliko poseduju Fc fragment, mogu posredovati i u ubijanju ćelija koje ispoljavaju membransku formu TNF- $\alpha$ aktivacijom drugih ćelija imunskog sistema ili sistema komplementa ili modulisati funkciju ćelija koje ispoljavaju receptore za Fc fragmanet i ostvarivati efektorske funkcije nezavisno od njihove sposobnosti da blokiraju/neutrališu TNF- $\alpha$.

Ključne reči: TNF- $\alpha$ inhibitori; neutralizacija TNF- $\alpha$; TNF receptori; transmembranski TNF- $\alpha$ 